\title{
Physiological quality of maize seeds produced under soil water deficit conditions
}

\author{
Fernando H. B. Machado ${ }^{1}$, Andréia M. S. de S. David ${ }^{1}$, Silvânio R. dos Santos ${ }^{1}$, Josiane C. Figueiredo ${ }^{2}$, \\ Cleisson D. da Silva ${ }^{1} \&$ Danúbia A. C. Nobre ${ }^{3}$ \\ ${ }^{1}$ Universidade Estadual de Montes Claros, Janaúba, MG, Brasil. E-mail: fernandobogard@yahoo.com.br - ORCID: 0000-0001-9448- \\ 0102; andreiamssdavid@yahoo.com.br - ORCID: 0000-0002-2747-5941; silvanio.santos@unimontes.br - ORICD: 0000-0003-0245-9184; \\ denercleisson5@gmail.com - ORICD: 0000-0003-4330-7144 \\ ${ }^{2}$ Universidade Federal de Pelotas, Pelotas, RS, Brasil. E-mail: josycantuaria@yahoo.com.br - ORCID: 0000-0001-7105-1241 \\ ${ }^{3}$ Universidade Federal dos Vales do Jequitinhonha e Mucuri, Diamantina, MG, Brasil. E-mail: danubia_nobre@yahoo.com.br (Corresponding \\ author) - ORCID: 0000-0002-5034-4480
}

\begin{abstract}
Crop strategies focused on the rational use of water are required in semiarid regions. Thus, the objective of this work was to evaluate the physiological quality of maize seeds produced under soil water deficit conditions. Five irrigation water depth were established, based on the field capacity $(100,85,70$, 55 and 40\%), to control the available water for two maize hybrids (2B-587 and DKB-390). A randomized block design was used, with a split-plot arrangement and four repetitions. The plots consisted of irrigation water depths, and the subplots consisted of maize hybrids. The seed water concentration, germination, and vigor were determined after the harvest, using data from first germination counting, seedling emergence, germination speed index, seedling length, and accelerated aging, electrical conductivity, and modified cold tests. The maize hybrid DKB-390 showed better physiological potential under the soil water deficit conditions evaluated. The irrigation water depths lower than $70 \%$ of field capacity resulted in decreases in soil water contents and affected negatively the physiological quality of the maize seeds produced.
\end{abstract}

Key words: Zea mays L., germination, vigor, water deficit, water management

\section{Qualidade fisiológica de sementes de milho produzidas sob limitações de água no solo}

RESUMO: Em região semiárida as estratégias de cultivo que visem o uso racional da água devem ser aplicadas. Neste sentido, objetivou-se avaliar a qualidade fisiológica de sementes de milho produzidas sob limitações de água no solo. Foram estabelecidas cinco reposições de água no solo, baseadas na capacidade de campo (100, 85, 70, 55 e 40\%), proporcionando condições controladas de água para dois híbridos de milho (2B 587 e DKB 390). O delineamento experimental utilizado foi em blocos casualizados em esquema de parcelas subdivididas, com quatro repetições, ficando as reposições de água nas parcelas e os híbridos nas subparcelas. Após a colheita das sementes determinaram-se o teor de água, a germinação e o vigor (primeira contagem de germinação, emergência de plântulas, índice de velocidade de germinação, comprimento de plântulas, envelhecimento acelerado, condutividade elétrica e teste de frio modificado). Para os híbridos em condições de restrição hídrica, o DKB 390 expressou melhor potencial fisiológico. Lâminas de reposição inferior a 70\% da capacidade de campo, viabilizou a redução de água no solo e afetou negativamente a qualidade fisiológica das sementes de milho produzidas.

Palavras-chave: Zea mays L., germinação, vigor, déficit hídrico, manejo de água 


\section{INTRODUCTION}

Several factors compromise the production and contribute to low maize crop yields, and two of them is related to water: the lack of genotypes tolerant to water deficit, and the nonuniformity of rainfall, mainly the occurrence of dry spells during critical stages of the crop development (Sousa et al., 2015). Therefore, the use of irrigation management is one of the technologies available to fix these irregular rainfalls and improve the water supply to plants.

Information on water consumption during the crop cycle is essential for the dimensioning of irrigation management systems, and contributes to increases of yield and optimization of water resources (Santos et al., 2014).

Moreover, maize hybrids that are tolerant to water deficit or present a better use of the available water in the soil have been identified, enabling the selection of genotypes that can produce high-quality seeds even under water stress conditions (Abreu et al., 2014).

Vigorous maize seeds affect directly the initial growth of plants and their competitiveness with weeds, which present lower growth, influencing the grain yield (Dias et al., 2010). Moreover, high-vigor maize seeds are more resistant to low water availability conditions, favoring the plant establishment in the field even under such conditions (Tekrony \& Egli, 1991). This is due to the fast emergence and high performance of the seeds, which result in a better uniformity, development, and quality of the harvested product (Marcos Filho, 2015a).

Considering that seeds are subjected to adverse conditions in arid and semiarid regions, the objective of this study was to evaluate the physiological quality of maize seeds produced under soil water deficit conditions.

\section{Material AND Methods}

The experiment was conducted from March to August 2017, at the Experimental Area of the Department of Agricultural Sciences of the Universidade Estadual de Montes Claros (DCA/UNIMONTES), in Janaúba, MG, Brazil (15²9' 44.4" $\mathrm{S}$, and $43^{\circ} 16^{\prime} 8.2^{\prime \prime} \mathrm{W}$, and $544 \mathrm{~m}$ of altitude). The climate of the region is Aw, tropical with dry winter, according to the Köppen classification (Alvares et al., 2013).

Seeds of two maize hybrids (2B-587 and DKB-390) were used; they were produced in the $2015 / 2016$ crop season by the Empresa Brasileira de Pesquisa Agropecuária (EMBRAPA Milho e Sorgo).

The soil of the experimental area was classified as Typic Udifluvent; it presented total water storage capacity of $38 \mathrm{~mm}$ in the first $0.2 \mathrm{~m}$ depth, due to high contents of medium and fine sands in the sand fraction. Fertilizers were applied at planting and as topdressing based on the soil chemical characteristics (0 to 20, and 20 to $40 \mathrm{~cm}$ layers), as recommended for the crop by Ribeiro et al. (1999).

Five irrigation water depths (IWD) were established, based on the field capacity $(100,85,70,55$, and $40 \%)$, to control the available water for two maize hybrids (2B-587 and DKB-390). A randomized block experimental design was used, with a split-plot arrangement and four repetitions. The plots consisted of the IWD, and the subplots consisted of the maize hybrids.

The area was divided into plots composed of four lateral irrigation lines of $4 \mathrm{~m}$ length, with drippers spaced $0.33 \mathrm{~m}$ apart, and rows spaced $1.0 \mathrm{~m}$ apart, totaling an area of $16 \mathrm{~m}^{2}$ per plot. Soil moisture sensors (Watermark') were installed at $0.1 \mathrm{~m}$ and $0.3 \mathrm{~m}$ depths in each plot during the soil preparation, representing the 0-0.2 and 0.2-0.4 m layers, respectively.

The IWD were based on the readings of the moisture sensors ( 0.1 and $0.3 \mathrm{~m}$ of depth). The readings during the crop cycle were converted into soil moisture by water retention curves, which were developed using local soil samples of each layer.

The plots consisted of two subplots composed of two lateral irrigation lines; the sowing spacing was $0.3 \mathrm{~m}$ between simple rows, $0.2 \mathrm{~m}$ between plants, and $0.7 \mathrm{~m}$ between double rows; the evaluation area consisted of the central $2 \mathrm{~m}$ of each subplot, totaling $1 \mathrm{~m}^{2}$.

The seeds were sowed on March 06, 2017 to a depth of 0.05 $\mathrm{m}$, using eight seeds per meter of the planting furrow. The irrigation system was evaluated on the same date, and showed average emitter flow of $2.42 \mathrm{~L} \mathrm{~h}^{-1}$ and average application efficiency of $95.4 \%$. Technical recommendations required for an adequate crop development were adopted after sowing, and the plants were thinned at 15 days after sowing (DAS), leaving five plants per linear meter.

The average air temperature and air relative humidity during the experiment were $24.8{ }^{\circ} \mathrm{C}$ and $53.8 \%$, respectively. Soil samples were collected weekly to evaluated the real soil moisture, before and after sowing, up to the end of the experiment; these data were used to calibrate the values obtained by the moisture sensors, and to assess instabilities in the moisture sensors.

The initial irrigation was similar for all treatments, increasing the soil moisture to the field capacity to promote a uniform development of plants. However, the readings of the moisture sensors at 15 DAS did not coincide with the real soil moistures assessed in the field; thus, the irrigations were based on the oven method to determine the water depth to be used in each soil water condition. The treatments were differentiated at 22 DAS, according to the irrigation water depths based on the moisture sensors.

The maize hybrids presented flowering at the same time, probably due to the water stress. The maize ears in the evaluation area of each subplot were harvested at 120 DAS, placed in plastic bags, and taken to the Seed Analysis Laboratory of the UNIMONTES.

The ears were manually threshed and the seeds were placed in paper bags and maintained at $70 \%$ air relative humidity and $25 \pm 3{ }^{\circ} \mathrm{C}$ for seven days. Four repetitions of 50 seeds per treatment were evaluated, using the same experimental design.

Seed water concentration, germination, and vigor were determined after the harvest, using data from first germination counting, seedling emergence, germination speed index, seedling length, and accelerated aging, electrical conductivity, and modified cold tests.

The seed water concentration was determined by the standard oven method at $105 \pm 3{ }^{\circ} \mathrm{C}$, for $24 \mathrm{~h}$, according to the methodology described in the Rules for Seed Analysis (Brasil, 2009). 
The seed germination was evaluated in Germitest papers wetted with distilled water at 2.5 -fold the dry paper weight. The rolls were placed in a germinator at temperature of $25^{\circ} \mathrm{C}$. The seedlings and seeds were evaluated at 4 (first counting) and 7 (germination) DAS, and the results were expressed in percentages of normal seedlings (Brasil, 2009).

The seedling emergence was evaluated under laboratory conditions $\left(25 \pm 3{ }^{\circ} \mathrm{C}\right)$; the seeds were sown to a depth of $0.05 \mathrm{~m}$ in plastic trays containing sterilized washed sand as substrate (Brasil, 2009). The sand moisture was maintained with the aid of sprayers, according to the need of the plant. The seedlings were evaluated at 7 DAS, and the results were expressed in percentage of emerged normal seedlings (shoots exposed above the substrate surface).

The emergence speed index (ESI) was evaluated by daily counting of the number of emerged seedlings. The ESI was calculated at the end of the test, using the formula described by Maguire (1962).

The accelerated aging test was carried out using seeds distributed uniformly on an aluminum sheet inside a plastic box (gerbox) containing $40 \mathrm{~mL}$ of distilled water. The boxes were covered and maintained in a Biochemical Oxygen Demand (BOD) incubator at $41^{\circ} \mathrm{C}$ for $72 \mathrm{~h}$ (Panobianco \& Marcos Filho, 2001). Then, the seeds were subjected to germination test, and the results were expressed in percentage of normal seedlings at 4 DAS (Brasil, 2009).

The electrical conductivity test was carried out by weighing seeds in a precision balance and placing them in 200-mL plastic cups containing $75 \mathrm{~mL}$ of distilled water. The cups were kept in a BOD incubator at $25^{\circ} \mathrm{C}$ for $24 \mathrm{~h}$ and, then, the solution was read using a portable conductometer (DM-31). The results were expressed in $\mu \mathrm{S} \mathrm{cm}^{-1} \mathrm{~g}^{-1}$ of seeds (Vieira et al., 2002).

The modified cold test was carried out using paper rolls wetted with distilled water at 2.5 -fold the paper weight. After sowing, the rolls were placed in plastic bags that were closed with rubber bands and maintained in a BOD incubator at 10 ${ }^{\circ} \mathrm{C}$ for 7 days. Then, the rolls were transferred from the plastics bags to a germinator at $25^{\circ} \mathrm{C}$; the number of normal seedlings were counted at $4 \mathrm{DAS}$, and the results were expressed in percentages (Barros et al., 1999).

The data were subjected to analysis of variance; the effects of the maize hybrids were studied by the $\mathrm{F}$ test at $\mathrm{p} \leq 0.05$, whereas the effects of the IWD were studied by regression analysis, choosing the models that better represent the data based on their coefficients of significance and coefficients of determination $\left(\mathrm{R}^{2}\right)$.

\section{Results ANd Discussion}

The seed water concentrations, which were determined as an initial procedure, were 10.2 and $10.8 \%$ for the maize hybrids 2B-587 and DKB-390, respectively, indicating uniformity of moisture between the samples evaluated. This similar moisture is important to prevent effects on the physiological quality evaluation tests because of differences in metabolic activity, moistening speed, and seed deterioration intensity (Steiner et al., 2011).

The final moisture of the seeds produced is related to their water loss after reaching the physiological maturity stage, which is affected by air relative humidity and temperature, regardless of the water stress conditions during the seed formation (Oliveira et al., 2015).

The interaction between maize hybrids and irrigation water depths (IWD) was significant $(\mathrm{p} \leq 0.05)$ for emergence speed index and accelerated aging (Table 1 ). The other variables were affected by isolated effects, except germination.

Despite the high germination percentage, the maize hybrids and IWD evaluated had no effects on this variable (Table 2). Similar results were found by Galbiatti et al. (2004), who reported that seed germination percentage is not affected by irrigation depths and maize hybrids, varying from 92 to $95 \%$ under the environmental conditions of Jaboticabal, SP, Brazil.

The maize hybrids presented different seed physiological quality (Table 2). Seeds from the maize hybrid DKB-390 presented higher means for first germination counting than

Table 2. Germination (GER), first germination counting (FGC), seedling emergence (SE), modified cold test (MC) and electrical conductivity (EC) of maize seeds (mean \pm standard deviation) of the hybrids 2B-587 and DKB-390

\begin{tabular}{lcc}
\hline \multirow{2}{*}{ Variables } & \multicolumn{2}{c}{ Maize hybrids } \\
\cline { 2 - 3 } GER (\%) & $2 \mathrm{~B}-\mathbf{5 8 7}$ & DKB-390 \\
FGC (\%) & $91 \pm 10.1 \mathrm{a}$ & $93 \pm 5.5 \mathrm{a}$ \\
SE $(\%)$ & $62 \pm 22.3 \mathrm{~b}$ & $80 \pm 9.5 \mathrm{a}$ \\
$\mathrm{MC}(\%)$ & $94 \pm 6.4 \mathrm{~b}$ & $97 \pm 3.3 \mathrm{a}$ \\
$\mathrm{EC}\left(\mu \mathrm{S} \mathrm{cm}^{-1} \mathrm{~g}^{-1}\right)$ & $61 \pm 16.3 \mathrm{~b}$ & $77 \pm 6.6 \mathrm{a}$ \\
\hline
\end{tabular}

Means followed by the same letter in the rows are not significantly different at $p \leq 0.05$ by F test

Table 1. Analysis of variance for germination (GER), first germination counting (FGC), seedling emergence (SE), emergence speed index (ESI), and accelerated aging (AA), electrical conductivity (EC), and modified cold test (MC) of maize seeds from hybrid plants produced under different irrigation water depths (IWD) based on the field capacity

\begin{tabular}{|c|c|c|c|c|c|c|c|c|}
\hline \multirow{3}{*}{$\begin{array}{l}\text { Sources } \\
\text { of variation }\end{array}$} & \multirow{3}{*}{ DF } & \multicolumn{7}{|c|}{ Mean squares } \\
\hline & & GER & FGC & SE & & $\overline{\mathbf{A A}}$ & EC & $\overline{M C}$ \\
\hline & & & $(\%)$ & & EDI & (\%) & $\left(\mu S \mathrm{~cm}^{-1} \mathrm{~g}^{-1}\right)$ & (\%) \\
\hline IWD & 4 & $43.750^{\text {ns }}$ & $207.6^{\star}$ & $39.35^{\text {ns }}$ & $0.949^{\text {ns }}$ & $446.1000 *$ & $1924.810^{*}$ & $78.65^{\text {ns }}$ \\
\hline Error A & 12 & 29.35 & 41.4 & 18.016 & 0.418 & 99.56 & 42.5 & 119.85 \\
\hline Hybrids (Hb) & 1 & $202.5^{\text {ns }}$ & 2992.9* & $115.600 *$ & $12.916^{\star}$ & $577.6^{\star}$ & $378.225^{\star}$ & $2722.5^{*}$ \\
\hline IWD $\times \mathrm{Hb}$ & 4 & $16.25^{\text {ns }}$ & $126.9^{\text {ns }}$ & $53.350^{\text {ns }}$ & $1.218 *$ & $499.1^{*}$ & $30.037^{\text {ns }}$ & $57.75^{\mathrm{ns}}$ \\
\hline Error B & 15 & 48.7 & 247.333 & 18.06 & 0.185 & 83.33 & 47.693 & 157.1 \\
\hline Block & 3 & 398.766 & 1874.233 & 45.6 & 0.204 & 1387.73 & 159.131 & 517.433 \\
\hline Means & & 92.25 & 71.05 & 95.2 & 8.66 & 68.8 & 27.87 & 69.15 \\
\hline CV1 A (\%) & & 5.87 & 9.06 & 4.46 & 7.47 & 14.5 & 23.39 & 15.83 \\
\hline CV2 B (\%) & & 7.56 & 22.13 & 4.46 & 4.98 & 13.27 & 24.77 & 18.13 \\
\hline
\end{tabular}

DF - Degrees of freedom; ns - Not significant, and * - Significant at $\mathrm{p} \leq 0.05$ by F test 
those from the hybrid 2B-587, indicating lower vigor for the latter. According to Abud et al. (2013), the first germination counting is based on the fact that the more vigorous seeds germinate faster.

Similar to the first germination counting, maize seeds of the hybrid DKB-390 presented higher vigor, according to the seedling emergence evaluation and modified cold test (Table 2). The high-quality seeds of the maize hybrid DKB-390 can be related to characteristics of the hybrid and to a better adaptation of these plants to the climate conditions of the north region of Minas Gerais state, Brazil, during the seed production. Magalhães et al. (2012) also found better performance for DKB390 when compared to other maize hybrids under the same climate conditions of the north of Minas Gerais.

The electrical conductivity of seeds of the maize hybrid DKB-390 was lower than that of seeds of the hybrid 2B-587 (Table 2). This lower electrical conductivity was due to a lower release of exudates, indicating a higher physiological potential (vigor) and lower disarrangement of seed cell membranes (Castro et al., 2016).

The electrical conductivity test shows the vigor of seeds related to the integrity of the cell membrane system. The differences found were probably related to the genetic constitution of the evaluated materials.

Regarding the effects of IWD on the vigor of the maize seeds produced, the results of the first germination counting (Figure $1 \mathrm{~A})$ fitted to a quadratic model $\left(\mathrm{p} \leq 005 ; \mathrm{R}^{2}=85.66 \%\right)$. The IWD of $40 \%$ of field capacity (FC) had $64.0 \%$ normal seedlings in the first counting, which reached the maximum of $75.22 \%$
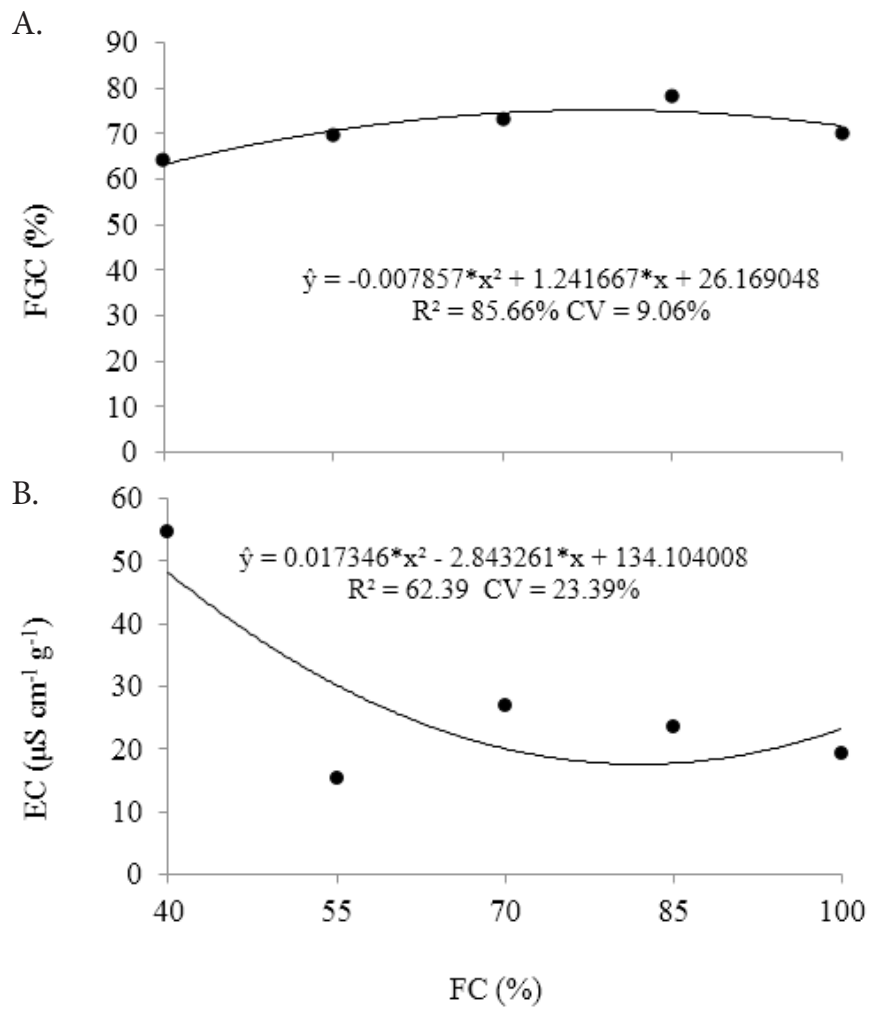

* Significant at $\mathrm{p} \leq 0.05$ by $\mathrm{F}$ test

Figure 1. First germination counting (FGC) (A) and electrical conductivity (EC) (B) of maize seeds from hybrid plants subjected to irrigation water depths based on the field capacity (FC) when using an IWD of $79.22 \%$ FC, and then decreased $11.0 \%$, ending up with $70.5 \%$ normal seedlings when using the IWD of $100 \%$ FC.

The water deficit decreases leaf area and stomatal closure and accelerates leaf senescence and abscission, making the plant to develop several mechanisms to tolerate this stress, affecting dry matter accumulation of seeds in formation (Taiz \& Zeiger, 2013). Therefore, considering the results found in the present study, it can compromise the physiological quality of the seeds produced.

The results of vigor of seeds by the electrical conductivity (EC) test (Figure 1B) fitted to a quadratic model ( $\mathrm{p} \leq 0.05$; $\left.\mathrm{R}^{2}=62.39 \%\right)$. The seeds harvested from plants subjected to the IWD of $40 \%$ FC presented higher EC $\left(54.47 \mu \mathrm{S} \mathrm{cm}^{-1} \mathrm{~g}^{-1}\right)$, indicating a higher release of nutrients and, therefore, low viability.

According to Panobianco et al. (2007), the higher the disarrangement of the cell membrane system, the lower the seed physiological potential. Therefore, the IWD of 70 and $85 \%$ FC resulted in seeds with higher vigor by presenting lower release of nutrients; this denotes a proper arrangement of the cell membrane system during the process of water absorption by seeds. However, the IWD above $85 \%$ FC resulted in decreases in seed vigor.

Considering the interaction between the factors for the emergence speed index (ESI), and the effect of the maize hybrids within each IWD (Table 3), the maize hybrid DKB390 presented higher emergence speed index (ESI) in the treatments with IWD of 100,85 , and $70 \%$ FC. However, the ESI of the hybrids in the treatments with IWD of 55 and $40 \%$ FC (soil water deficit conditions) were similar.

ESI is a quantitative measure that relates the number of emerged seedlings to the number of days after sowing. The higher the ESI, the higher the emergence speed index (Ferreira \& Borghetti, 2004); therefore, this test allowed to quantify the vigor of the maize seeds.

The treatments with IWD of 100 and $85 \%$ FC favored the seed germination of the maize hybrid DKB-390 after the accelerated aging test (Table 3 ). The results were significantly higher than those for the maize hybrid 2B-587. The IWD of 70,55 , and $40 \%$ FC resulted in significant differences in seed germination of the maize hybrids after the accelerated aging test.

Considering the effect of IWD within each maize hybrid (Figure 2A), the ESI results for seeds of the maize hybrid DKB390 fitted to an increasing linear model ( $\left.\mathrm{p} \leq 0.05 ; \mathrm{R}^{2}=95.51 \%\right)$. A positive effect was found for ESI, which was proportional to the increase in the IWD.

The highest ESI (9.93) was found for maize seeds produced with IWD of $100 \%$ FC. The ESI of seeds of the maize hybrid DKB-390 was $10.18 \%$ higher under the IWD of $100 \%$ FC when compared to that under the IWD of $40 \%$ FC. Seeds with higher ESI are more vigorous because a higher emergence speed. The ESI of seeds of the maize hybrid 2B-587 was not affected by the IWD, presenting a mean of 8.09 (Figure 2A).

Considering the accelerated aging test (Figure 2B) and the IWD within each maize hybrid, the results fitted to an 
Table 3. Emergence speed index (ESI) and accelerated aging (AA) (mean \pm standard deviation) of maize seeds from hybrid plants subjected to different irrigation water depths based on the field capacity

\begin{tabular}{|c|c|c|c|c|c|}
\hline \multirow{2}{*}{$\begin{array}{c}\text { Maize } \\
\text { hybrids }\end{array}$} & \multicolumn{5}{|c|}{ Field capacity (\%) } \\
\hline & 100 & 85 & 70 & 55 & 40 \\
\hline \multicolumn{6}{|c|}{ ESI } \\
\hline $2 \mathrm{~B}-587$ & $8.1 \pm 0.2 b$ & $8.4 \pm 0.4 b$ & $7.2 \pm 0.5 b$ & $9.0 \pm 0.2 b$ & $8.4 \pm 0.6 a$ \\
\hline DKB-390 & $9.8 \pm 0.4 \mathrm{a}$ & $9.4 \pm 0.5 a$ & $9.2 \pm 0.4 \mathrm{a}$ & $8.4 \pm 1.0 \mathrm{a}$ & $8.3 \pm 0.7 \mathrm{a}$ \\
\hline \multirow{2}{*}{\multicolumn{6}{|c|}{ CV (\%) }} \\
\hline & & & & & \\
\hline $2 B-587$ & $75 \pm 11.6 b$ & $50 \pm 8.5 b$ & $61 \pm 26.6 \mathrm{a}$ & $66 \pm 10.6 \mathrm{a}$ & $70 \pm 16.5 a$ \\
\hline DKB-390 & $88 \pm 13.1 \mathrm{a}$ & $79 \pm 11.5 \mathrm{a}$ & $75 \pm 12.5 \mathrm{a}$ & $58 \pm 5.2 \mathrm{a}$ & $65 \pm 20.5 a$ \\
\hline CV (\%) & \multicolumn{5}{|c|}{8.44} \\
\hline
\end{tabular}

Means followed by the same letter in the rows are not significantly) different at $\mathrm{p} \leq 0.05$ by $\mathrm{F}$ test
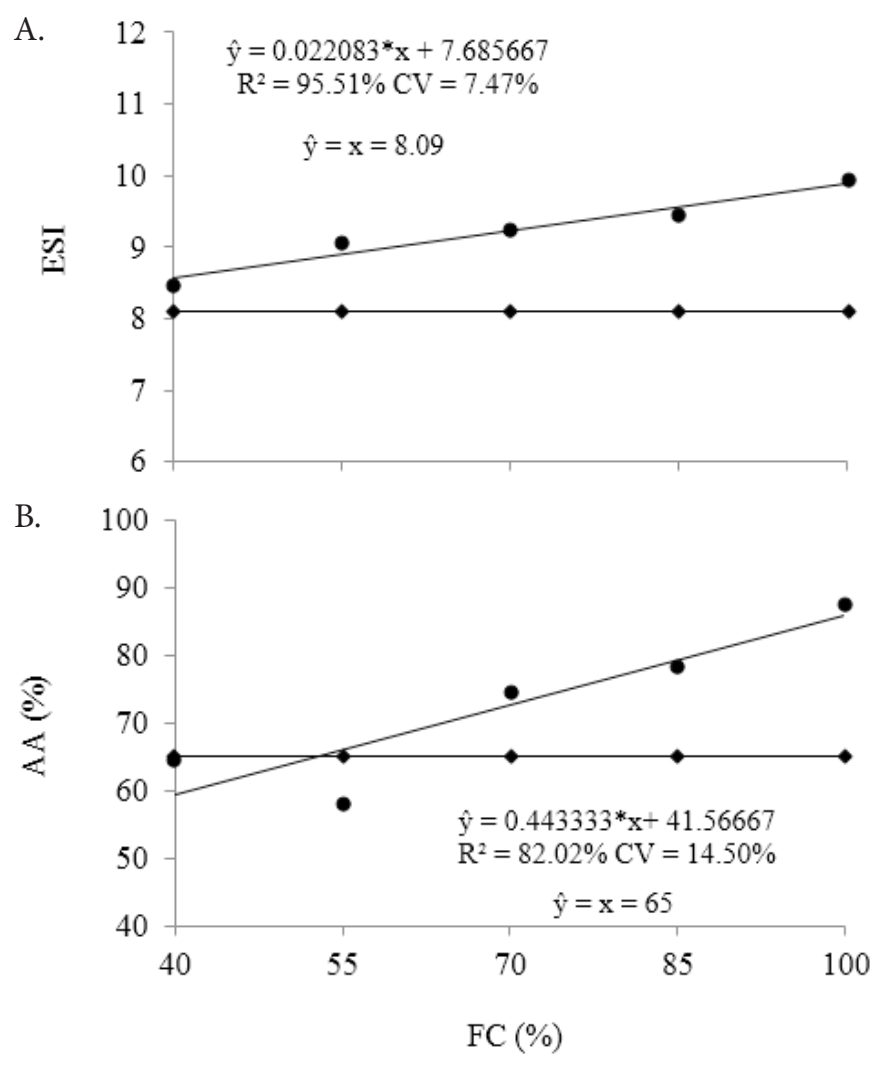

Significant at $\mathrm{p} \leq 0.05$ by $\mathrm{F}$ test

Figure 2. Emergence speed index (ESI) (A) and accelerated aging (AA) (B) of maize seeds from hybrid plants subjected to irrigation water depths based on the field capacity (FC)

increasing linear model for the maize hybrid DKB-390, i.e., the germination of aged seeds increased as the IWD based on the pre-established FC was increased.

Seeds from plants under IWD of $100 \%$ FC presented higher germination percentages $(87.5 \%)$ than those from plants under IWD of $40 \%$ FC (64.5\%) (Figure $2 \mathrm{~B}$ ). The seed germination of the maize hybrid DKB-390 grown under the IWD of $100 \%$ FC was $26.28 \%$ higher after the accelerated aging when compared to that of plants grown under the IWD of $40 \%$ FC.

The seed germination of the maize hybrid 2B-587, after the accelerated aging, was not affected by the IWD, presenting a mean germination of $65 \%$ (Figure $2 \mathrm{~B}$ ).

The accelerated aging test is recognized as the most important for evaluation of seed vigor by providing consistent information. It considers that lots of high-vigor seeds maintain their viability over time when subjected to severe air temperature and air relative humidity conditions (Marcos Filho, 2015b).
The present study confirmed this and the test showed the physiological potential of the maize hybrid DKB-390.

The physiological responses of seeds from plants under water deficit conditions vary according to the severity and duration of the stress, plant phenological stage and genetic material (Shao et al., 2008). In the present study, the maize hybrid DKB-390 evaluated in the municipality of Janaúba, MG, Brazil, presented better seed physiological quality under the irrigation water depths tested, denoting the inherent characteristics of the maize hybrid, which presented tolerance to the environmental conditions of the study region.

\section{Conchusions}

1. The maize hybrid DKB-390 presented higher physiological potential under soil water deficit conditions.

2. The irrigation water depths lower than $70 \%$ of field capacity decreased soil water contents and affected negatively the physiological quality of the maize seeds produced.

\section{ACKNowledgements}

The authors thank the Fundação de Amparo à Pesquisa do Estado de Minas Gerais (FAPEMIG), the Conselho Nacional de Desenvolvimento Científico e Tecnológico (CNPq), and the Coordenação de Aperfeiçoamento de Pessoal de Nível Superior - Brasil (CAPES; Financial Code 001) for granting of scholarships, and the Embrapa Milho e Sorgo for donating genetic materials.

\section{Literature Cited}

Abreu, V. M. de; Pinho, E. V. de R. von; Pinho, R. G. von; Naves, G. M. de F.; Silva Neta, I. C.; Guimarães, R. M.; Carvalho, M. R. de Physiological performance and expression of isozymes in maize seeds subjected to water stress. Journal of Seed Science, v.36, p.40-47, 2014. https://doi.org/10.1590/S2317-15372014000100005 Abud, H. F.; Araújo, E. F.; Araújo, R. F.; Araújo, A. V.; Pinto, C. M.

F. Qualidade fisiológica de sementes das pimentas malagueta e biquinho durante a ontogênese. Pesquisa Agropecuária Brasileira, v.48, p.1546-1554, 2013. https://doi.org/10.1590/S0100204X2013001200003

Alvares, C. A.; Stape, J. L.; Sentelhas, P. C.; Gonçalves, J. L. de M.; Sparovek, G. Köppen's climate classification map for Brazil. Meteorologische Zeitschrift, Stuttgart, Germany: Schweizerbart Science Publishers. v.22, p.711-728, 2013. https:// doi.org/10.1127/0941-2948/2013/0507 
Barros, A. S. R.; Dias, M. C. L. L.; Cicero, S. M.; Krzyzanowski, F. C. Teste de frio. In: Krzyzanowski, F. C.; Vieira, R. D.; França Neto, J. de B. (eds.). Vigor de sementes: Conceitos e testes. Londrina: Abrates, 1999. Cap.5, p.1-12.

Brasil. Ministério da Agricultura, Pecuária e Abastecimento. Regras para Análise de Sementes. Brasília: MAPA, 2009. 399p.

Castro, E. de M.; Oliveira, J. A.; Lima, A. E. de; Santos, H. O. dos; Barbosa, J. I. L. Physiological quality of soybean seeds produced under artificial rain in the pre-harvesting period. Journal of Seed Science, v.38, p.1421, 2016. https://doi.org/10.1590/2317-1545v38n1154236

Dias, M. A. N.; Mondo, V.H. V.; Cicero, S. M. Vigor de sementes de milho associado à mato-competição. Revista Brasileira de Sementes, v.32, p.93-101, 2010. https://doi.org/10.1590/S0101-31222010000200011

Ferreira, A. G.; Borghetti, F. Germinação: Do básico ao aplicado. Porto Alegre: Artmed, 2004. 323p.

Galbiatti, J. A.; Borges, M. J.; Bueno, L. F.; Garcia, A.; Vieira, R. D. Efeito de diferentes períodos de irrigação no desenvolvimento, produção e qualidade de sementes na cultura do milho (Zea mays L.). Engenharia Agrícola, v.24, p.301-308, 2004. https://doi. org/10.1590/S0100-69162004000200008

Magalhães, P. C.; Souza, T. C. de; Albuquerque, P. E. P. de. Efeitos do estresse hídrico na produção de grãos e na fisiologia da planta de milho. Sete Lagoas: Embrapa Milho e Sorgo, 2012. 37p. Boletim de Pesquisa e Desenvolvimento, 51

Maguire, J. D. Speed of germination: Aid in selection and evaluation for seedling emergence and vigor. Crop Science, v.2, p.176-177, 1962. https://doi.org/10.2135/cropsci1962.0011183X000200020033x

Marcos Filho, J. Fisiologia de sementes de plantas cultivadas. 2.ed. Londrina: Abrates, 2015a. 660p.

Marcos Filho, J. Seed vigor testing: An overview of the past, present and future perspective. Scientia Agricola, v.72, p.363-374, $2015 \mathrm{~b}$. https://doi.org/10.1590/0103-9016-2015-0007

Oliveira, F. de A. de; Medeiros, J. F. de; Alves, R. de C.; Lima, L. A.; Santos, S. T. dos; Régis, L. R. de L. Produção de feijão caupi em função da salinidade e regulador de crescimento. Revista Brasileira de Engenharia Agrícola e Ambiental, v.19, p.1049-1056, 2015. https://doi.org/10.1590/1807-1929/agriambi.v19n11p1049-1056
Panobianco, M.; Marcos Filho, J. Envelhecimento acelerado e deterioração controlada em sementes de tomate. Scientia Agricola, v.58, p.525-531, 2001. https://doi.org/10.1590/S010390162001000300014

Panobianco, M.; Vieira, R. D.; Perecin, D. Electrical conductivity as an indicator of pea seed aging of stored at different temperatures. Scientia Agrícola, v.64, p.119-124, 2007. https://doi.org/10.1590/ S0103-90162007000200003

Ribeiro, A. C.; Guimarães, P. T. G.; Alvarez V., V. H. Recomendação para o uso de corretivos e fertilizantes em Minas Gerais: Quinta Aproximação. Viçosa: Comissão de Fertilidade do Solo do Estado de Minas Gerais, 1999. 359p.

Santos, W. D. O.; Espínola Sobrinho, J.; Medeiros, J. F.; Moura, M. S. B.; Nunes, R. L. C. Coeficientes de cultivo e necessidades hídricas da cultura do milho verde nas condições do semiárido brasileiro. Irriga, v.19, p.559-572, 2014. https://doi.org/10.15809/ irriga.2014v19n4p559

Shao, H.; Chu, L.; Jaleel, C. A.; Zhao, C. Water-deficit stress induced anatomical changes in higher plants. Comptes Rendus Biologies, v.331, p.215-225, 2008. https://doi.org/10.1016/j.crvi.2008.01.002

Sousa, R. S.; Bastos, E. A.; Cardoso, M. J.; Ribeiro, V. Q.; Brito, R. R. Desempenho produtivo de genótipos de milho sob déficit hídrico. Revista Brasileira de Milho e Sorgo, v.14, p.49-60, 2015. https:// doi.org/10.18512/1980-6477/rbms.v14n1p49-60

Steiner, F.; Oliveira, S. S. C.; Martins, C. C.; Cruz, S. J. S. Comparação entre métodos para a avaliação do vigor de lotes de sementes de triticale. Ciência Rural, v.41, p.200-204, 2011. https://doi. org/10.1590/S0103-84782011005000011

Taiz, L.; Zeiger, E. Fisiologia vegetal. 5.ed. Porto Alegre: Editora Artemed, 2013. 954p.

Tekrony, D. M.; Egli, D. B. Relationship of seed vigor to crop yield: A review. Crop Science, v.31, p.816-822, 1991. https://doi. org/10.2135/cropsci1991.0011183X003100030054x

Vieira, R. D.; Penariol, A. L.; Perecin, D.; Panobianco, M. Condutividade elétrica e teor de água inicial das sementes de soja. Pesquisa Agropecuária Brasileira, v.37, p.1333-1338, 2002. https://doi.org/10.1590/S0100-204X2002000900018 